\title{
AN ANALYSIS OF FIGURATIVE LANGUAGE USED IN WESTLIFE'S SELECTED SONGS
}

\author{
Abdul Muhid Murtadho ${ }^{1}$ \\ Sekolah Tinggi Bahasa Asing IEC Jakarta \\ muhid@stibaiec-jakarta.ac.id
}

\author{
Amelia \\ amelia@gmail.com \\ Sekolah Tinggi Bahasa Asing IEC Jakarta
}

Murtadho, A.M. and Amelia. (2022). An Analysis of Figurative Language Used in Westlife's Selected Songs. Journal of English Language and literature, 7(1), 73-84. doi: 10.37110/jell.v7i1.145

Received: 02-02-2022

Accepted: 25-02-2022

Published:03-03-2022

\begin{abstract}
The purposes of this study are: (1) To find out the figurative language used in Westlife's selected songs (2) To know the general meaning of lyrics on the Westlife's selected songs. In analyzing of figurative language used in Westlife's selected songs lyrics, the writer using qualitative research methodology, the data is taken from several books and internet as well as. Based on research finding, the general meaning contained in Westlife"s selected songs lyric indirectly deliver to the listeners through the lyrics they wrote.The lyrics try to tell about human social life which contains happiness, sadness, loneliness and others. The writer could identified that most of figurative language which used in Westlife's selected songs lyric is "Hyperbole". The writer got the data from the table. Hyperbole has a great exaggeration used to emphasize a point.
\end{abstract}

Keywords: figurative Language, figurative meaning, song lyrics

\section{INTRODUCTION}

Poetry is one of the oldest genres in literature culture. Its earliest example go back to ancient Greek literature. In despite of this long tradition, it is harder to define any other genres. Poetry is closely related to the term "lyric", which derives etymologically from the Greek musical instrument "lyra" ("lyre" or "harp") and points to an origin in the sphere of music. Ancient Greek music and music the theory has fascinated scholars for centuries not only because of its intrinsic interest as a part of ancient Greek culture but also because the

${ }^{1}$ Corresponding Author
Greek's grand concept of music has continued to stimulate musical imaginations to the present day.

Unlike earlier treatments of the subject, lyre is aimed principally at the reader interested in the musical typologies, the musical instrument and especially the historical development of music theory and its transmission through the middle age. The term "poetry", however goes back to the Greek word "poico" ("to make to reduce"), indicating that the poet is the person who "makes" verse. Even though etymology sheds light on some of the aspects of the lyric and poetic, it can not offer a satisfactory explaination of the phenomenon as such 
(Klarer, 2013). Language can be defined as an arbitrary system of creative vocal symbols used as a means of communication among human beings. People need language to communicate, learn, argue, negotiate and celebrate. Language is also a system of conventional spoken, manual or written symbols. The functions of language include communication, emotional release, imaginative expression and the expression of identity.

According to Saussure (1998) language is the most obvious distinguishing feature because it allows each social group to feel like a separate entity from the others.

Lyrics in Western music are not only used to denotative meaning to express message from singer but also connotative meaning. Connotative meaning happens because the singer wishes to make emotion, agreement, condition, feeling, etc, for the listeners. Many kinds of literature give us so much information in which they use non literal meaning of words. For example, some lyrics on the songs use figurative language to make it more unique, interesting, imaginative and meaningful.

Figurative language is phrasing that goes beyond the literal meaning of words to get a message or point across (a way of saying one thing and meaning another). It is associated with lyric of the song uses figurative language. Here are some common types of figurative language. Among these are: simile, metaphor, personification, hyperbole, idiom, alliteration, irony, symbols, etc. But in general, the figurative language is differentiated into four groups, they are: confirmation, comparison, opposition, and allusion. These figurative language are well-known in society, and also in the field of education starting from elementary school up to the university level.

In Westlife's song a lot of lyric that reveal the feelings and emotions, as in the song example $M y$ Love, that lyric describes the longing of a man with his girlfriend who away from him. The beginning stanza that stated loneliness in his heart. Every activity he always thought on his girlfriend. This longing made him pray that in his dreams he can be found on his beloved in beautiful place. This lyric also illustrated the loyalty of a man who survived the distant lover.

\section{REVIEW OF LITERATURE}

\section{Language}

According to Saussure (1998) language is the most obvious distinguishing feature because it allows each social group to feel like a separate entity from the others.

Futhermore, Carroll (2013) argued that language is a systematic system of arbitrary sounds and sequences of language sounds that are used or can be used in communication between individuals by a group of humans and that gives names to objects, events, and processes in the human environment.

Besides, Language is widespread within the sense that all individuals of the human species have the capacity to memorize a dialect, it isn't shocking that nonspoken languages have created among nonhearing people. The more we learn almost the human phonetic capacity, the more it is evident that dialect securing and utilize are not subordinate on the capacity to deliver and listen sounds, but on a much more unique cognitive capacity, naturally decided, that accounts for the similitudes between spoken and sign dialects (Fromkin et al., 2003).

\section{Figurative Language}

Figurative language is language that can not be taken literally. Metaphorical dialect could be a frame of talk, to be specific the utilize of words in speech and composing to persuade or impact audience members and perusers. The word comes from the Greek explanatory rhetor which implies speaker or speaker. In antiquated Greek times, the rhetoric is undoubtedly an critical portion of an instruction and by a assortment of figure of speech because it is exceptionally critical and must be controlled totally by the Greek and Roman who gave the title to the different expressions of persuasion. Figurative dialect, figurative or "figure of speech" is metaphorical language, beautiful 
dialect that's utilized to promote and upgrade the impact by way of introducing and comparing an protest or a specific thing with objects or other things that are more common. In brief, the utilize of a certain figure of discourse may alter and cause the value of a specific flavor or essences.

According to Bergen (2007), figurative language differs from literal meaning yet is founded on it. The experiences that an individual has had in the environment are seen as crucial to the design of their cognitive capacities and behavior in an embodied approach to language. Internal simulation, based on previous actions and perceptions in the world, appears to be necessary for comprehending metaphorical language.

Dancygier \& Sweetser (2014) stated that figurative language was regarded to be one feature of what gives a document - especially a poetry composition - its specific esthetic value." It means that the audience receives a more lovely message than if he directly addresses the personal attributes of his subjects, such as kindness, charm, and beauty. It has the potential to promote emotional involvement, which could be precisely the aesthetic effect desired.

\section{Kinds of Figurative Language}

From the explaination above, it is considered that figurative language deals with language which utilize figure of discourse and language cannot be taken scholarly as it were and it is utilized to specific the inward feeling of the writer.

There are many types of figurative language:

\section{1) Metaphor}

Metaphor could be a express utilized in an creative to depict something in arrange to say that between the two things are the same qualities and it is work to the depiction more effective without utilizing sign posting.

Example: She is a shining star in her class.

Accroding to Picks (2015) Metaphor comes from the Greek, metaphora, meaning to carry or to exchange something. It is utilized to form a mental expression, a judgment and exchanges characteristics of a concept to another.

Metaphor may be a prime illustration, has customarily been the concern of the expressions and humanities. As of late, however, metaphor appears to have caught up the intrigued of researchers of diverse traditions and foundations. The concept of allegory itself, as well as the distinction between strict and metaphorical dialect, have ended up a multidisciplinary concern. Exacting dialect has been the dialect of science with its observational and sound modes of request, and metaphorical language that of the expressions and humanities. The intrigue nature and its exceptional significance in present day thought has moved allegory from a place on the fancy borders of talk to the core of educational questions: the mind's unending endeavor to form sense of reality (Leino \& Drakenberg, 1993).

R. Hussain (2014) defined the word representation is determined from the Greek word Metaphoria, which implied "to carry". Representation is a comparison of two distinctive wonders which share a few common focuses. It may be a kind of condensed comparison that some parts of it, like topic or similitudes markers are erased to communicate the meaning connotatively. The first definition of representation is communicated by Aristotle as "a shift carrying over a word from its normal use to the new one" For occurrence within the sentence the client is lord numerous qualities a ruler has, like impact, importance, power and so on are credited to a client. In the condensed mrtaphor ' ship of state'. The captain of a ship represents the government. The ocean speaks to the stream of time, awful climate shows a emergencies and need of wind signifies financial stagnation. In scholarly interpretation, representation is primilirily considered a metaphorical expression by which a word of express is modified from its exacting references to a unused and regularly wide field of reference.

2) Simile 
Rashid Hussain (2014) stated the word simile is derived from the Latin word which means "such as", technically it implies the comparison of two objects with some similarities. Simile is described explicitly by use of the words: such as, if as, as though, be like, like.

Example: Her smile is bright like the sun

According to Fadaee (2011) simile is an plain one which expressly and accurately clarifies the question and it is the primary and easiest strategy for conveying the excellence of message which is used in verse, exposition additionally normal discussions. Indeed children talking almost their wants, utilize likeness as a implies of comparison.

\section{3) Personification}

According to Gorys Keraf (2007) theory in the book entitled diction and stlye "personification could be a kind of fashion of metaphorical dialect that portrays lifeless objects or goods dormant as in the event that it has characteristics humanity." Personification is a special feature of metaphor, which make an analogy of inanimate objects act, talk, like humans.

Example: The sun is smiling at us.

\section{4) Apostrophe}

Apostrophe is a kind of style in the form of a transfer of message from the audience to something that is not present. This method is usually used by classical orators. In a speech delivered to a crowd, the orator suddenly directs his speech directly to something that is not present. To those who have died, or to an imaginary object or object or something abstract, so that he does not appear to be speaking to the audience (Keraf, 2007).

Example: Hi all of you who have shed your blood for this beloved homeland, grant us so that we can enjoy justice and freedom as you have fought for.

5) Hyperbole

Hyperbole is a figure of speech utilized to express overstated articulations which don't compare to reality but which are nevertheless not seen as lies. Hyperbole opens up a talk outline and builds up a modern center on information in discourse making that piece of data more striking than surrounding discourse. The accentuation hence made much obliged to different semantic-syntactic forms is reflected in prosody and motion with the use of focalization gadgets. At final, prosodic patterns and signals don't as it were strengthen verbal accentuation, they may completely contribute to the emphasis in a complementary way, and indeed constitute hyperbolic communicative acts by themselves. In the conclusion, we propose that hyperbole is utilized by speakers to build an individual, intersubjective character component (Ferré et al., 2016).

Example: She cried so long that she made a lake!

\section{6) Litotes}

Keraf (2007) states that litotes comes from Greek litos which means "simple". Litotes is a figure in which we say less but mean more, it is a explanatory figure in which a explanation is made unequivocal by denying a opposite.

Example: This house is the result of our small business.

7) Irony

Irony is a figure of speech and one of the foremost broadly- known scholarly gadgets, which is utilized to precise a solid feeling or raise a point. As characterized, Incongruity is the utilize of words to communicate a meaning that's inverse of what is really said.

Example: This is my brilliant daughter who failed out of college.

8) Metonymy

Metonymy is figure of speech that replaces the title of a thing with the title something else with which it is closely related. it means by which one entity stands for another, though representation could be a way in which one entity is seen as another (Fass, 1988).

Example: The Pentagon, for the Department of defense and offices of the U.S. Armed Forces. 


\section{9) Synecdoche}

Synecdoche is figure of speech to clarify a part of the object to state the total thing or something and a portion is substituted for a entirety or a entirety for a portion (Cornell et al., 2011).

Example: John bought a new set of wheels.

\section{0) Repetition}

Repetition is figure of speech that appears the consistent accentuation that is essential to pull in a reader's consideration on the key-word or a keyphrase of the content. It suggests rehashing sounds, words, expressions and clauses in a certain progression or indeed with no particular situation of the words, in order to supply accentuation. There's no confinement in utilizing repetition but too much reiteration can be gloomy and indeed ruin its elaborate impact. Repetition is also additionally frequently utilized in discourse, as a rhetorical device to bring consideration to an idea (Kemertelidze \& Manjavidze, 2013).

Example: Spring is flowers, spring is green grass, spring is rainy days.

\section{1) Alliteration}

Alliteration is figure of speech in which the same sound rehashes in a bunch of words or when there is a reiteration of sound inside a state or a sentence (Keraf, 2007).

Example: she sells seashells by the sheshore

\section{2) Idiom}

Idiom is a group of words whose meaning can not be clarified in term of the routine implications of the words that make up the piece of language. It modes of expression or expressions which are unconventional to a given dialect. They are the premise for understanding the language, since they constitute a huge portion of. it. They are seldom interpreted actually and often the lexicon is of small help in the determination of the meaning of a portionfar, expression. Such cases as "to make a beeline for," meaning to require the shortest course, and "to be short-handed," meaning to have deficiently offer assistance, are typical cases of figures of speech which cannot be understood from their grammatitiil development. Other idioms are composed of verbs and prepositions words, such as "to fill in" meaning to substitute for or to complete the spaces on a frame, or composed of verbs and intensifiers such as to "look forward," meaning to anticipate. Idioms have meanings other than the customary meanings of the words which compose them (Adkins, 1968).

Example: He cried crocodile tears (he cried fake tears).

According to Keraf (2007) states that figurative language can be categorized into four groups, those are:

\section{Figure of Comparison}

Figure of comparison divided into five groups, those are: simile, metaphor, personification, allegory, and anthitesis.

2. Figure of Contradiction

Figure if contradiction divided into seven groups, those are: hyperbole, litotes, irony, oxymoron, paronomasia, paralypsis, and zeugma.

\section{Figure of Correlation}

Figure if contradiction divided into seven groups, those are: metonymy, synecdoche, allusion, euphemism, ellipsis, inversion, and gradation.

4. Figure of Repetition

Figure of repetition divided into four groups, those are: alliteration, antanaclasys, chiasmus, and repetition.

\section{Definition of Song}

Songs are one of the foremost captivating and socially rich resources that can be effortlessly utilized in language classrooms.As Griffee say that "the word song refers to pieces of music that have words, especially popular songs such as those one hears on the radio." In the same field, Griffee (1992) also states that:

Songs have components in common with speech and poetry, they are a one of a kind shape. Both songs and speech are vocally delivered, are 
linguistically important and have song. Both songs and poetry use words to communicate meaning, both are as a rule composed down before publication, both can be put to music and both can be listened to.

Finally, it appears that a song could be a piece of melodic composition of words, verse, or lyric which is sung or articulated with balance of the voice which communicates the thought and feeling. Song is powerful. Numerous individuals can be moved to tears or other solid feelings by music, and tune can procure solid enthusiastic affiliations with individuals, events, and places. Song has individual quality that makes the listener respond as on the off chance that the songs were being sung for the listener personally.

\section{Definition of Lyric}

The word lyric is derived from the Middle French word "lyrique", which means "a short poem expressing emotion". It comes from the Latin word "lyricus" and the Greek word "lyrikos", which both mean "of or singing to the lyre." A lyre is a tiny stringed instrument that was traditionally used in ancient Greece to accompany singing or poetry recitation. The word lyric was first documented in English in the 1580s, and its variant meaning of song lyrics was first recorded in English in 1876.

Post (1999) stated that lyric poetry frequently invites intmate involvement, providing an opportunity to "converse" across time and civilizations, as well as inside a single society. The comment is so ubiquitous that it has practically vanished from view, particularly in aerly poetry criticism (and the language of literary studies in general) and also defined lyricas is a genre in which "the soul" speaks-in contrass to a more "socially specified self"-tells a significant, though not complete, reality about lyric: because it prompts instant identification with the speaker.

\section{METHOD}

In analyzing of figurative language used in Westlife's selected songs lyrics, the writer focuses on figurative language; using qualitative research methodology. The data for this analysis are taken from several books and internet as well as the lyrics. And to increase resources about the thesis the writer goes over understanding and listening to the music from Westlife.

The writer tries to analyze the information with concept for this research and she uses qualitative method in this study.

\section{FINDING AND DISCUSSION}

\section{The Figurative Language}

The writer has provided some kind of figurative language in chapter II of her thesis. She is going to find those kind of figurative language in her data through the Westlife's selected songs.

a) My Love

Table 1: Lyrics My Love

\begin{tabular}{|c|c|c|c|}
\hline No & Lyrics & $\begin{array}{l}\text { Types of Figurative } \\
\text { Language }\end{array}$ & Meaning \\
\hline 1. & $\begin{array}{l}\text { An empty street, an } \\
\text { empty house }\end{array}$ & $\begin{array}{l}\text { The lyric shows the use } \\
\text { of Symbol, because it } \\
\text { is a thing (could be an } \\
\text { object, person, } \\
\text { situation or action) } \\
\text { which is stand for } \\
\text { something else more } \\
\text { abstract. }\end{array}$ & $\begin{array}{l}\text { The writer describes what he is feeling } \\
\text { when he sees the road conditions are } \\
\text { so quiet, expressing it is void and how } \\
\text { unhappy he is when he is alone at } \\
\text { home. All the activities he did at home } \\
\text { felt empty. The "an empty street, an } \\
\text { empty house" means a symbol of } \\
\text { lonely. }\end{array}$ \\
\hline
\end{tabular}


2. A hole inside my The lyric shows the use The writer actually doesn't have a hole heart of Hyperbole, because in his heart, but it is just an expression it appears to be that describes that his heart is empty excessive. because someone he loves is far away from him. So to fill a hole in his heart, the writer expects someone special to close the hole back.

3. I'm all alone the This sentence shows Actually the room is an inanimate
rooms are getting the use of object that can't get smaller but life
smaller

4. And all my love, I'm This sentence is an The truly is, nothing hold for all future holding on forever example of a time or very long time, the writer just Hyperbole, because it wants to convey how he fell in love seems to be excessive. with someone. So, he want to hold on forever which means continously be with him and do not want to be separated.

5. Reaching for the love The lyric shows the use
that seems so far $\begin{aligned} & \text { of Hyperbole, because } \\ & \text { it appears to be } \\ & \text { excessive. }\end{aligned}$

In this case, the writer doesn't truly saying that want to reach very long distance. Reaching for the love that seems so far means someone who has not realized how much the writer loves that person.

6. And hope my dreams
$\begin{array}{ll}\text { will take me there lyric shows the use } \\ \text { of Hyperbole, because }\end{array}$
it appears to be
excessive.

The writer doesn't really say dreams can take him away, but the sentence means he hopes in a dream he can meet someone he hopes for. After he meets someone he loves, he thinks to take himself wherever he wants, because for the writer, she is a nice dream.

\footnotetext{
7. I wonder how, I This lyrics example of Repeats this to emphasize how to get wonder why Repetition, because it her out of his mind I wonder where they is a literary device in are which a word or phrase is repeated two or more
} 
times.

8. Where the skies are The lyric consist of The writer uses in expressing the blue Symbol desire to meet someone is when the sky looks blue and tries to tell how he wants to feel again the atmosphere when he meets his lover where the skies are blue. The word blue sky means a romantic weather symbol.

\begin{tabular}{|c|c|c|c|}
\hline 9. & $\begin{array}{l}\text { Overseas from coast } \\
\text { to coast, to find the } \\
\text { place I love the most }\end{array}$ & $\begin{array}{l}\text { This sentence shows } \\
\text { Metonymy, because it } \\
\text { replaces the title of a } \\
\text { thing with the title } \\
\text { something else with } \\
\text { which it is closely } \\
\text { related. }\end{array}$ & $\begin{array}{l}\text { This meaning of the word "the place" } \\
\text { is "someone". }\end{array}$ \\
\hline 10. & $\begin{array}{l}\text { Where the fields are } \\
\text { green }\end{array}$ & $\begin{array}{l}\text { The lyric shows } \\
\text { Symbol }\end{array}$ & $\begin{array}{l}\text { The writir uses in expressing a very } \\
\text { beautiful and harmonious places. } \\
\text { Westlife uses a green field to } \\
\text { symbolize the beautiful natural } \\
\text { scenery when meeting with his lover. } \\
\text { The writer uses the green field symbol } \\
\text { to commemorate the places he has } \\
\text { visited with his cherish. The word } \\
\text { green field means a symbol of } \\
\text { naturalness. }\end{array}$ \\
\hline
\end{tabular}

b) Soledad

Table 2: Lyrics Soledad

\begin{tabular}{|c|c|c|c|}
\hline No & Lyrics & $\begin{array}{c}\text { Types of Figurative } \\
\text { Language }\end{array}$ & Meaning \\
\hline 1. & $\begin{array}{l}\text { If only you could } \\
\text { see the tears }\end{array}$ & $\begin{array}{l}\text { The lyric shows the use } \\
\text { of Symbol }\end{array}$ & $\begin{array}{l}\text { The "tears" means sign of heart can't } \\
\text { say in expressing emotion. The writer } \\
\text { left by a lover which makes him cry. So, } \\
\text { the tears in the lyrics mean a symbol of } \\
\text { sadness. }\end{array}$ \\
\hline 2. & $\begin{array}{l}\text { If only you could } \\
\text { see } \\
\text { If only you could } \\
\text { heal }\end{array}$ & $\begin{array}{l}\text { This lyric consists of } \\
\text { Repetition }\end{array}$ & $\begin{array}{l}\text { This figure usually use in words } \\
\text { repetition that have meaning as } \\
\text { emphasize to Soledad. }\end{array}$ \\
\hline
\end{tabular}




\begin{tabular}{|c|c|c|c|}
\hline 3. & $\begin{array}{l}\text { In the world you } \\
\text { left behind }\end{array}$ & $\begin{array}{l}\text { The data shows } \\
\text { Metonymy }\end{array}$ & $\begin{array}{l}\text { The word "the world you left behind" is } \\
\text { substituted for the word "last memory" }\end{array}$ \\
\hline 4. & $\begin{array}{l}\text { There's an image } \\
\text { of your face }\end{array}$ & $\begin{array}{l}\text { Metonymy, because the } \\
\text { name of a thing is } \\
\text { substituted for that of } \\
\text { another closely } \\
\text { associated with it. }\end{array}$ & $\begin{array}{l}\text { The word "face" means girlfriend, } \\
\text { sweetheart or lover }\end{array}$ \\
\hline 5. & $\begin{array}{l}\text { I would give my } \\
\text { life away }\end{array}$ & $\begin{array}{l}\text { The sentence shows the } \\
\text { use of Hyperbole }\end{array}$ & $\begin{array}{l}\text { This lyric tells us that the author's life } \\
\text { will give to Soledad. }\end{array}$ \\
\hline 6. & $\begin{array}{l}\text { In my heart you } \\
\text { were the only }\end{array}$ & $\begin{array}{l}\text { This lyrics example of } \\
\text { Hyperbole }\end{array}$ & $\begin{array}{l}\text { The writer describes the atmosphere of } \\
\text { someone who fall in love and crazy in } \\
\text { love. }\end{array}$ \\
\hline 7. & $\begin{array}{l}\text { And your memory } \\
\text { lives on }\end{array}$ & $\begin{array}{l}\text { The lyric shows } \\
\text { Paradox, because it } \\
\text { occurs in a statement } \\
\text { that at first strikes us as } \\
\text { self contradictory but } \\
\text { that on reflection make } \\
\text { some sense. }\end{array}$ & $\begin{array}{l}\text { Two different meaning of "lives" are } \\
\text { contrasted, lives in spiritiual values and } \\
\text { psychology values. }\end{array}$ \\
\hline 8. & $\begin{array}{l}\text { That is calling out } \\
\text { your name }\end{array}$ & $\begin{array}{l}\text { The lyric shows } \\
\text { Personification, is a } \\
\text { figure of speech in } \\
\text { which a thing, an } \\
\text { animal, or an abstract } \\
\text { term is made human. }\end{array}$ & $\begin{array}{l}\text { The word "that" is refer to the } \\
\text { angel, this lyric describes the } \\
\text { animation, because an angel cannot call } \\
\text { someone as the human do. }\end{array}$ \\
\hline 9. & $\begin{array}{l}\text { Time will never } \\
\text { change the things } \\
\text { you've told me }\end{array}$ & $\begin{array}{l}\text { The lyric shows } \\
\text { Personification }\end{array}$ & $\begin{array}{l}\text { The abstract term "time" is made } \\
\text { human who can change the things. }\end{array}$ \\
\hline 10. & $\begin{array}{l}\text { Love will bring us } \\
\text { back to you and me }\end{array}$ & $\begin{array}{l}\text { The lyric shows } \\
\text { Personification }\end{array}$ & $\begin{array}{l}\text { This lyric try to imagine that love able } \\
\text { to make more closed and the using } \\
\text { 'bring' word in this lyric usually used } \\
\text { by human. }\end{array}$ \\
\hline
\end{tabular}

\section{The Most Figurative Language Used}

In this part, the writer will conclude what kind of figurative language mostly used in the data's that could be seen on the table below: 
Table 3: The Most Used Figurative Language

\begin{tabular}{ccc}
\hline Figurative Language & My Love & Soledad \\
\hline Symbol & 3 & 1 \\
\hline Hyperbole & 4 & 2 \\
\hline Personification & 1 & 3 \\
\hline Repetition & 1 & 1 \\
Metonymy & 1 & 2 \\
\hline Paradox & - & 1 \\
\hline
\end{tabular}

\section{The General Meaning of Westlife's Selected Songs}

Each song is composed certainly does have a message directed to the listeners and the readers. The message is coordinated with the intention that they get the impression after listening in and reading the lyric. Based on the theory, message is things to be conveyed on to the audience by the singers through their songs. So the message contained in Westlife's selected songs lyric indirectly deliver to the listener and reader through the lyrics they wrote.

\subsection{My Love}

This song is idealize for all levels and the circle is being hit by romance or yearning for a loved one. In the lyrics of this song, the songwriter is attempting to describe and convey to us. From the starting of the verse of this song portrays how much empty the feelings of someone who feels lonely, that no anybody who went with him at that time. The loneliness that he felt caused a really deep longing to lover that made him feel the emptiness of the heart. Ilustrates that the longing he has made him supplicate and trust that in his rest he was given a dream that took him to go some place. A place with wonderful views of the beach and ocean, blue sky and green field bring it back to see the confront of his lover and enjoy the beautiful place with a lover.

The lyrics of this song still gives explanation and appear his longing for his beloved lovers, to each movement that he does in life and joking with his friends can not dispense the emotions of longing his lover. He can not control his thoughts about the longing for his lover. It still ilustrates how much he missed the best day with his sweetheart. Where he missed the moment when he was with his lover, having fun until he sang his favorite song with a lover him.

In the lyrics of this song, there is also a verse that describes how difficult it is to achieve the love he has. It is said that he always maintained his lover so far and with all the serousness of his love he was able to fight. In addition, the lyrics of this song also tells the desires of a lover who trusts to always be together with his lover and live together until the end of time. It is explained that he needed to hold his lover in his embrace with a sincere and continous love is always there during his life.

\subsection{Soledad}

This song means about someone who misses the person he loves so much, that he can't do anything without thinking about her, even when he is on the road. The word "Soledad" comes from Spanish which means "Solitude", a state of social isolation, a state of being alone to calm himself. He would gladly sacrifice this life full of misery. He had lost control of his abilities and the emotions of his departure haunted him. Slowly he destroys himself. It is a popular belief that time can heal everything, but the singer believes that time will never change her feelings about someone he loves. Moving 
forward was the furthest thing on his mind, he was sure that one day they could meet again, and held on to that hope. After all, love conquers all.

\section{The Moral Value}

During writing this thesis, the writer finds there are some moral values in this thesis. Each lyric that is written certainly contains a message adressed to listeners and readers. The message is directed with the purposeful that they get an impression after listening and reading the lyrics. The message contained in Westlife's lyrics is indirectly conveyed to the audiences through the lyrics they write.

The lyrics of Westlife's selected songs try to tell about human social life which contains love, loyalty, longing, happiness, sadness, loneliness and others. The lyrics of Westlife's selected songs which contain figurative language are very helpful in understanding the song. This song is effective for English learners who want to improve their English skills in analyzing lyrics that contain figurative language and meaning of the songs.

\section{CONCLUSION}

The figurative language found in Westlife's selected songs lyric. In this part writer tries to analyze figurative language in Westlife's selected songs lyric, Westlife use various figurative language like hyperbole, symbol, personification, repetition, metonymy, paradox in their songs. The writer examines the figurative language by understanding and looking for lyrics that contain figurative language.

The meaning of the song could be analyzed in Westlife's selected songs lyric. By analyzing figurative language, the writer not only found the lyric that contains of figurative language but also meaning of the song lyrics, every songs in this thesis has different meaning. "My Love" tells about how much empty the feelings of someone who feels lonely, that no anybody who went with him at that time. The loneliness that he felt caused a really deep longing to lover that made him feel the emptiness of the heart. Ilustrates that the longing he has made him supplicate and trust that in his rest he was given a dream that took him to go some place. A place with wonderful views of the beach and ocean, blue sky and green field bring it back to see the confront of his lover and enjoy the beautiful place with a lover. "Soledad" describes about someone special or girlfriend who was gone, he expresses his mind. This is done since this song lyric tells us about the deepest feeling toward someone or lover called Soledad. She is one of the beautiful girls who evokes the singer's emotion of love.

The most figurative language could be identified After analyzing the data, the writer could identified that most of figurative language which used in lyrics of Westlife's selected songs lyric is "Hyperbole". The writer got the data from the table. Hyperbole has a great exaggeration used to emphasize a point, and is used for expressive or comic effect. For example, in lyrics "A hole inside my heart" and "I would give my life away" that give impossible to do by human being but the using figure to make the lyric more interesting to listen and understand.

\section{REFERENCES}

Adkins, P. G. (1968). Teaching Idioms and Figures of Speech to Non-Native Speakers of English. The Modern Language Journal, 52(3), 148-152. https://doi.org/10.1111/j.15404781.1968.tb01884.x

Bergen, B. (2007). Mental simulation in literal and figurative language understanding BT - The literal/non-literal distinction. The Literal/NonLiteral Distinction, January 2005, 1-17. papers2://publication/uuid/

Carroll, J. B. (2013). The Study of Language. Harvard University Press. https://doi.org/10.4159/harvard.9780674331730

Cornell, S., Digital, L. A., Law, C., Publications, F., \& Torres, G. (2011). Synecdoche.

Dancygier, B., \& Sweetser, E. (2014). Figurative Language. Cambridge University Press. https://books.google.co.id/books?id=hdTSAgA AQBAJ\&lpg=PR14\&ots=bbUAoZ6H9I\&dq=D 
ancygier\%2C Barbara \%26 Sweetser\%2C Eve. (2014\%2C p.1). Figurative Language\%2C Cambridge Textbooks in Linguistics \&lr\&pg=PR6\#v=onepage \&q=Dancygier, Barbara \& Sweetser, Eve. (2014

Fadaee, E. (2011). Symbols, metaphors and similes in literature: A case study of \&quot;Animal Farm\&quot; Journal of English and Literature, 2(2), $19-27$. http://www.academicjournals.org/ijel

Fass, D. (1988). Metonymy and metaphor. 177-181. https://doi.org/10.3115/991635.991671

Ferré, G., Hyperbole, M., Communication, M., \& Mouton, D. G. (2016). Gaëlle Ferré To cite this version: HAL Id: hal-01422552 Multimodal Hyperbole. 3(1), 25-50.

Fromkin, V., Rodman, R., \& Hyams, N. (2003). An Introduction to Language Seventh Edition. 36. http://www.wadsworth.com

Griffee, D. T. (1992). Songs in Action. Prentice-Hall New York. https://books.google.co.id/books/about/Songs_i n_Action.html?id=Ao1wQgAACAAJ\&redir_es $\mathrm{c}=\mathrm{y}$

Hussain, R. (2014). Metaphors and similes in Literature. International Journal of Humanities and Social Science Invention ISSN (Online, 3(9), 2319-7722. www.ijhssi.org

Kemertelidze, N., \& Manjavidze, T. (2013). Stylistic Repetition, Its Peculiarities and Types in Modern English. European Scientific Journal, 7881(July), 1857-7881.

Keraf, G. (2007). Diksi dan Gaya Bahasa. PT. Gramedia Pustaka Utama Jakarta. https://books.google.co.id/books?id=2zm9pAb UHP8C\&printsec $=$ frontcover $\# \mathrm{v}=$ onepage $\& \mathrm{q} \& \mathrm{f}$ $=$ false

Klarer, M. (2013). An introduction to literary studies. In An Introduction to Literary Studies. https://doi.org/10.4324/9780203068915

Leino, A.-L., \& Drakenberg, M. (1993). Metaphor: An Educational Perspective Research Bulletin
No:84.

Post, J. (1999). English Lyric Poetry. The Early Seventeenth Century. https://www.taylorfrancis.com/books/mono/10. 4324/9780203006313/english-lyric-poetryjonathan-post

Saussure, F. de. (1998). "Nature of the Linguistic Sign." In The Critical Tradition: Classic Texts and Contem- porary Trends. Martin's Press, 1998. 832

-835 .

https://doi.org/10.4159/harvard.9780674331730 